\section{FACTORS AFFECTING RESTING ENERGY EXPENDITURE AND URINARY NITROGEN IN VENTILATED CRITICALLY ILL CHILDREN}

\author{
C. Jotterand ${ }^{1}$, J. Depeyre ${ }^{1}$, M.-H. Perez ${ }^{2}$, \\ J. Cotting ${ }^{2}$
}

${ }^{1}$ Department of Nutrition and Dietetics, University of Applied Sciences, Geneva, ${ }^{2}$ Paediatric Intensive

Care Unit, University Hospital of Lausanne, Lausanne, Switzerland

Rationale: This longitudinal study aimed to assess resting energy expenditure and urinary nitrogen in ventilated critically ill children.

Methods: Resting energy expenditure (REEm) was measured daily by indirect calorimetry in children with expected mechanical ventilation $\geq 72$ hours and $\mathrm{FiO} 2 \leq 60 \%$. Urinary nitrogen was measured by chemoluminescence. Nitrogen balance was calculated as the difference between nitrogen intake and total nitrogen loss. Comparisons were made with Recommended Dietary Allowances (RDA).

Results: We included 74 children, 42 boys and 32 girls with a mean age $( \pm S D)$ of $24.2 \pm 22.9$ months. 407 indirect calorimetry and urinary nitrogen measurements were performed. REEm was $55.3 \pm 12.2 \mathrm{kcal} / \mathrm{kg} / \mathrm{d}$ and corresponded to $54.8 \pm 11.1 \%$ of RDA. REEm was lower in children 4-8 years old than in other groups $(p<0.05)$. When measurements were performed in children with body temperature $>37.5^{\circ} \mathrm{C}$, REEm was higher $(58.7 \pm 12.1 \mathrm{kcal} / \mathrm{kg} / \mathrm{d})$ than when body temperature was $<37.5^{\circ} \mathrm{C}(54.3 \pm 12.1 \mathrm{kcal} / \mathrm{kg} / \mathrm{d} ; p=0.003)$. REEm was lower on days with neuromuscular blocking drugs $(55.5 \pm 11.4 \mathrm{kcal} / \mathrm{kg} / \mathrm{d})$ than without $(58.6 \pm 12.4$ $\mathrm{kcal} / \mathrm{kg} / \mathrm{d} ; p=0.031)$. Mean urinary nitrogen was $0.2 \pm 0.06 \mathrm{~g} / \mathrm{kg} / \mathrm{d}$. Children aged $4-8$ years old had higher urinary nitrogen than younger children $(p<$ $0.001)$ and required more protein $(2.22 \mathrm{~g} / \mathrm{kg} / \mathrm{d})$ to achieve zero nitrogen balance. No difference of REEm and urinary nitrogen was observed among medical/surgical diagnosis, sepsis/no sepsis, cardiopulmonary bypass/no cardiopulmonary bypass, normal nutritional status/malnutrition.

Conclusion: Resting energy expenditure only reached $55 \%$ of RDA and was mainly affected by fever, beside age. Surprisingly, urinary nitrogen was higher in older children who required more protein than RDA to achieve zero nitrogen balance.

\section{PROTEIN AND ENERGY INTAKE ON DAY 4 AT THE PICU: PREDICTOR FOR OUTCOME?}

\author{
M.E. Augustus, J.F. Olieman, K.F.M. Joosten \\ Intensive Care Children, Erasmus MC Sophia \\ Childrens Hospital, Rotterdam, The Netherlands
}

Background: Critically ill children are extremely vulnerable to develop malnutrition during stay on the intensive care. The aim of the study is to evaluate nutritional goals for protein and energy on day 4 of admission in relation with outcome.

Patients and methods: Nutritional intake of 332 children (189 male, median age 0.13 year) with various diagnoses were analyzed on day 4 . Goals for protein- and energy-intake were: 0-12 months $\geq 1.8 \mathrm{gr} / \mathrm{kg} / \mathrm{d}, \geq 1 \mathrm{yr} \geq 1.2 \mathrm{gr} / \mathrm{kg} / \mathrm{d}$ and at least Resting Energy Expenditure $+30 \%$. Malnutrition was defined as an SD-score for weight for age (WFA) $<-2$.

Results: The prevalence of malnutrition was $20 \%$ ( $60 \%$ male). Median length of hospital stay was 11 days (range 5-347). 47 children died. There was a sign. difference in protein intake and SD score between survivors and non-survivors $>1 \mathrm{yr}$ (1.7 vs $1.1 \mathrm{~g} / \mathrm{kg} / \mathrm{dy}$ and SD -0.7 vs -1.9$)$. Overall protein intake was met in $65 \%$ and energy intake was met in $75 \%$. Subgroup analysis showed that the lowest energy and protein intake was given in children aged 7-12 yr. There was no significant correlation between energy- or protein-intake and length of hospital stay.

Conclusion: The prevalence of malnutrition of children admitted to the PICU is high. On day 4 of admission approximately $2 / 3$ of the children met their energy and protein goals. Children who died received significant less protein. Further research should focus on the relation between malnutrition and outcome parameters like respiratory and circulatory support and secondary infections. 